Research Article

\title{
Electrochemical Removal of Rare Earth Element in LiCl-KCl Molten Salt
}

\author{
Gha-Young Kim (D), Junhyuk Jang, Seungwoo Paek, and Sung-Jai Lee \\ Nuclear Fuel Cycle Process Research Division, Korea Atomic Energy Research Institute, Daejeon 34057, Republic of Korea \\ Correspondence should be addressed to Gha-Young Kim; gkim@kaeri.re.kr
}

Received 11 February 2020; Accepted 15 July 2020; Published 10 August 2020

Academic Editor: Peter Ivanov

Copyright (c) 2020 Gha-Young Kim et al. This is an open access article distributed under the Creative Commons Attribution License, which permits unrestricted use, distribution, and reproduction in any medium, provided the original work is properly cited.

\begin{abstract}
This study was carried out to examine the removal of rare earth (RE) elements by electrodeposition for the purification and reuse of $\mathrm{LiCl}-\mathrm{KCl}$ salt after electrorefining and electrowinning. The electrochemical behavior of RE elements (Dy and $\mathrm{Gd}$ ) in $\mathrm{LiCl}-\mathrm{KCl}-$ $\mathrm{DyCl}_{3}-\mathrm{GdCl}_{3}$ at $500^{\circ} \mathrm{C}$ was investigated using the cyclic voltammetry $(\mathrm{CV})$ technique using $\mathrm{Mo}$ and $\mathrm{Mg}$ electrodes. It was observed that the reduction potential of the RE elements shifted at the Mg electrode owing to the alloy formation with Mg (RE-Mg alloy). Subsequently, a series of potentiostatic electrolysis tests were conducted to remove the RE elements in the salt and check the formation of deposits at the $\mathrm{Mg}$ and Mo electrodes. The scanning electron microscopy-energy dispersive X-ray spectroscopy (SEM/EDS) technique was used to confirm that the reduced RE metals were deposited on the surface of the Mg electrode. However, no significant deposit on the Mo electrode was observed, and a mud-like deposit was found on the bottom of the electrochemical cell. The salt analysis performed by employing the inductively coupled plasma-optical emission spectrometry (ICP-OES) indicated that the removal efficiency of $\mathrm{Dy}^{3+}$ and $\mathrm{Gd}^{3+}$ through electrodeposition was $83.5 \sim 95.2$ and 91.6 95.2\%, respectively.
\end{abstract}

\section{Introduction}

Pyroprocessing is an option which enables to recover the useful nuclear elements from spent fuel and to recycle them for fast reactors $[1,2]$. Pyroprocessing consists of several unit processes to separate, recover, and store the radioactive elements in the spent fuels $[3,4]$. After head-end process, the spent oxide fuel is immersed and reduced in $650^{\circ} \mathrm{C} \mathrm{LiCl}$ at the electrolytic reduction process. Then, the reduced spent fuel is transferred into an electrorefiner which contains a eutectic $\mathrm{LiCl}-\mathrm{KCl}$ melt with some portion of $\mathrm{UCl}_{3}$ at $500^{\circ} \mathrm{C}$. Uranium is recovered using solid cathode (i.e., electrorefining) [5-7] and uranium and transuranic elements are recovered using liquid cathode (i.e., electrowinning) [8-10]. After both of the recovery steps such as electrorefining and electrowinning, there are abundant amounts of rare earth (RE) elements in the salt. Consequently, the molten salt electrolyte containing RE elements should be properly treated to minimize salt waste, to fabricate a durable waste form, and to reuse the purified salt electrolyte in electrorefining and electrowinning. Besides, RE elements are key elements in industries and often used as additives to improve properties of alloy such as thermal and mechanical properties and corrosion resistance [11].

To separate RE elements from the salt, various processes have been employed, such as ion-exchange [12], zone freezing method [13], and phosphate precipitation [14, 15]. However, these require a specific device for solid salt detachment and/or layer separation and an additional process such as distillation. Some researchers attempted to extract $\mathrm{RE}$ from the molten solvent via electrochemical methods. They have used an $\mathrm{Al}$ electrode in a chloride salt [16-19], Ni and $\mathrm{Cu}$ electrodes in a fluoride salt [20], W electrode in $\mathrm{MgCl}_{2}$-containing salt [21], and $\mathrm{Mg}$ electrode [22-24]. Especially, Yang et al. reported that the selective extraction of Dy was carried out using Mg electrode [22]. We thought that the electrochemical removal of $\mathrm{RE}$ in salt enables to the purification and reuse without salt transfer step from 
electrorefiner/electrowinner to another reactor. The objective of the present study was to examine the removal of RE elements by electrodeposition using Mo and $\mathrm{Mg}$ electrode. The use of $\mathrm{Mg}$ was considered as it is a reactive material that forms RE-Mg alloys and Mo is an inert electrode widely used in electrochemical experiments. Cyclic voltammetry (CV) measurements were obtained to observe the redox peaks of $\mathrm{RE}$ elements by using $\mathrm{Mo}$ and $\mathrm{Mg}$ electrodes in $\mathrm{LiCl}-\mathrm{KCl}$ containing $\mathrm{DyCl}_{3}$ and $\mathrm{GdCl}_{3}$ at $500^{\circ} \mathrm{C}$. Subsequently, a series of constant-potential electrolysis tests was performed to remove $\mathrm{Dy}^{3+}$ and $\mathrm{Gd}^{3+}$ in the salt and a cross-sectional analysis of deposit was carried out by SEM/EDS technique.

\section{Materials and Methods}

All the experiments were performed in a glove box with an $\mathrm{Ar}(\mathrm{g})$ atmosphere $\left(\mathrm{H}_{2} \mathrm{O}<1 \mathrm{ppm} ; \mathrm{O}_{2}<3 \mathrm{ppm}\right)$. A mixture of LiCl-KCl eutectic salt (99.99\% purity, Sigma-Aldrich) and $\mathrm{RECl}_{3}$ (RE: Dy and Gd, 99.99\% purity, Alfa-Aesar) was prepared in an alumina crucible $(30 \mathrm{~mm}$ inner diameter, $50 \mathrm{~mm}$ height). Three-electrode system was used for the experiment. A Mo wire ( $1 \mathrm{~mm}$ diameter, Nilaco) and $\mathrm{Mg}$ plate $(2 \mathrm{~mm} \times 5 \mathrm{~mm}$, Alfa-Aesar $)$ was used as a working electrode. The electrode surface area was determined by width, thickness, and dipping height. A glassy carbon rod ( $3 \mathrm{~mm}$ diameter, Alfa-Aesar) and a $\mathrm{Ag} / \mathrm{AgCl}(1 \mathrm{~mol} \%$ ) in the Pyrex tube was used as a counter electrode and a reference electrode, respectively. All the tests were conducted at $500^{\circ} \mathrm{C}$. The electrochemical experiments were carried out by Bio Logic SP-300 potentiostat/galvanostat. The electrodeposition tests were carried out by applying a constant potential. The applied potential value for each electrodeposition run was adjusted with respect to be more slightly negative than EMP before run. Table 1 shows the detailed experimental conditions. The cross-sectional image and the elemental analysis of the RE deposit were observed with scanning electron microscopy (SEM; Hitachi, S-8010) in conjunction with energy-dispersive X-ray spectroscopy (EDS; Horiba, EX-250 X-max). The salt composition was analyzed via an inductively coupled plasma-optical emission spectrometer (ICP-OES; ACTIVA M, Horiba Jobin Yvon SAS).

\section{Results and Discussion}

The reduction potential of $\mathrm{Dy}^{3+}$ and $\mathrm{Gd}^{3+}$ in $\mathrm{LiCl}-\mathrm{KCl}$ at $500^{\circ} \mathrm{C}$ was identified using a Mo and $\mathrm{Mg}$ electrode. Figure 1 shows the cyclic voltammogram using Mo electrode (surface area: $0.165 \mathrm{~cm}^{2}$ ) with a scan rate of $100 \mathrm{mV} / \mathrm{s}$. The cathodic peaks at about $-1.92 \mathrm{~V}$ and $-2.04 \mathrm{~V}$, represent the reduction reactions of $\mathrm{Dy}^{3+}$ to $\mathrm{Dy}$ and $\mathrm{Gd}^{3+}$ to $\mathrm{Gd}$, respectively. In case of $\mathrm{Mg}$ electrode (surface area: $0.502 \mathrm{~cm}^{2}$ ), the reduction peaks were not clearly observed, as shown in Figure 2. It is because of the formation of RE-Mg alloy. At a scan rate of $3 \mathrm{mV} / \mathrm{s}$, low height of two peaks were found at -1.88 and $-1.94 \mathrm{~V}$, which were assumed to be the formation of Dy-Mg alloy and Gd-Mg alloy, respectively [22]. The phase diagram shows that one Dy-Mg alloy (DyMg) and four Gd-Mg alloys ( $\mathrm{GdMg}, \mathrm{GdMg}_{2}, \mathrm{GdMg}_{3}$, and $\mathrm{GdMg}_{5}$ ) can exist at $500^{\circ} \mathrm{C}$
TABLE 1: Experimental conditions of the potentiostatic electrodeposition tests.

\begin{tabular}{llcc}
\hline Run \# & Cathode & Applied potential (V) & Time (h) \\
\hline 1 & Mg strip & -1.90 & 12 \\
2 & Mo wire & -1.90 & 11 \\
3 & Mo coil & -1.90 & 21 \\
4 & Mo coil & -1.92 & 21 \\
5 & Mo coil & -1.94 & 5 \\
\hline
\end{tabular}

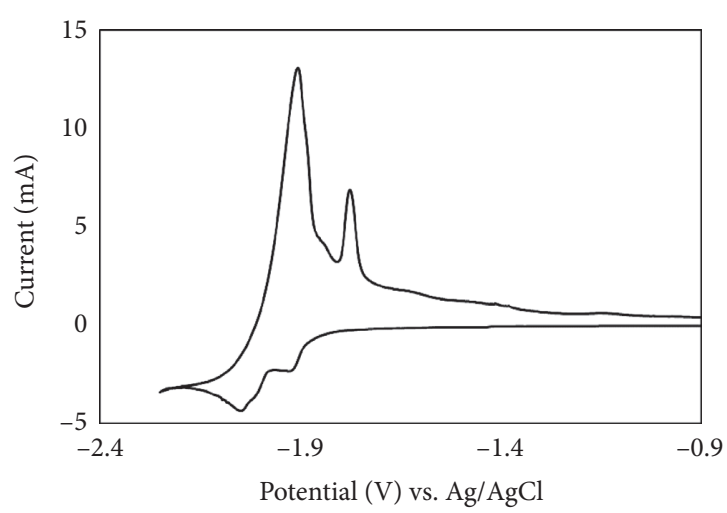

Figure 1: Cyclic voltammogram of Mo electrode in LiCl-KCl-0.2 wt $\% \mathrm{DyCl}_{3}-1$ wt $\% \mathrm{GdCl}_{3}$ at $500^{\circ} \mathrm{C}$ with a scan rate of $100 \mathrm{mV} / \mathrm{s}$.

[25], but one peak of Dy-Mg alloy and one peak of Gd-Mg alloy were observed in this study.

A series of potentiostatic electrolysis tests were subsequently conducted to remove the RE elements $\left(\mathrm{Dy}^{3+}\right.$ and $\mathrm{Gd}^{3+}$ ) in $\mathrm{LiCl}-\mathrm{KCl}-0.15 \mathrm{wt} \% \mathrm{DyCl}_{3}-0.59 \mathrm{wt} \% \mathrm{GdCl}_{3}$ at $500^{\circ} \mathrm{C}$ using $\mathrm{Mg}$ and Mo electrode. Figure 3 shows the results of $\mathrm{CV}$ measurements before and after each electrolysis run. In run 1, the Mg plate (surface area: $1.04 \mathrm{~cm}^{2}$ ) was used as a working electrode to recover the RE elements in the form of RE-Mg alloy and to remove these elements from the salt by applying $-1.9 \mathrm{~V}$ for approximately $12 \mathrm{~h}$. As shown in Figure 3, the redox peak heights of $\mathrm{Dy}^{3+}$ and $\mathrm{Gd}^{3+}$ clearly decreased after the run 1. However, another anodic peak appeared at $-1.82 \mathrm{~V}$, likely, because of the presence of $\mathrm{Mg}^{2+}$ in the salt, which was contributed by the $\mathrm{Mg}$ electrode. In particular, owing to the small size of the employed experimental cell, the distance between the anode and cathode $(10 \sim 15 \mathrm{~mm})$ was not sufficient to ensure that the cathodic reaction was independent of the anodic reaction. Because the $\mathrm{Cl}_{2}(\mathrm{~g})$ generated on the graphite anode surface may affect the $\mathrm{Mg}$ cathode, it results in the producing of $\mathrm{MgCl}_{2}$ in the salt [24]. This was confirmed by the salt analysis by ICP-OES technique, as shown in Figure 4. Initially, $\mathrm{Mg}^{2+}$ did not exist in the salt, but after run 1 , the concentration of $\mathrm{Mg}^{2+}$ increased to $0.16 \mathrm{wt} \%$. To prevent the dissolution of $\mathrm{Mg}$ electrode, the cathode was changed to inert Mo electrode in the subsequent electrolysis runs. In run $1, \mathrm{Dy}^{3+}$ was decreased from 0.15 to $0.12 \mathrm{wt} \%$ and $\mathrm{Gd}^{3+}$ was decreased 0.59 to $0.40 \mathrm{wt} \%$. Even though the applied potential was $-1.9 \mathrm{~V}$, which is slightly positive than the reduction peak potential of $\mathrm{Gd}^{3+}$ on $\mathrm{Mg}$ electrode, those two elements were reduced. This result was not consistent with the study of Yang et al. [22]. In their 


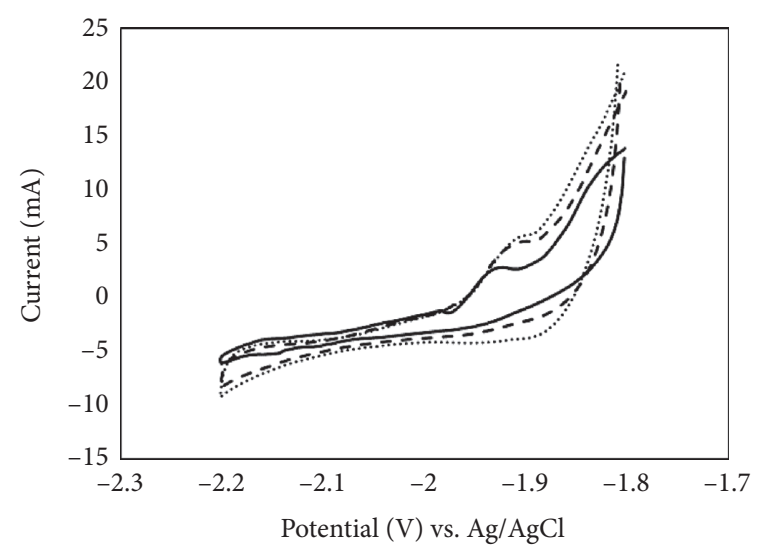

FIGURE 2: Cyclic voltammograms of Mg electrode in LiCl-KCl-0.2 wt $\% \mathrm{DyCl}_{3}-1 \mathrm{wt} \% \mathrm{GdCl}_{3}$ at $500^{\circ} \mathrm{C}$ with various scan rates ($1 \mathrm{mV} / \mathrm{s},---3 \mathrm{mV} / \mathrm{s}, \cdots 5 \mathrm{mV} / \mathrm{s}$ ).

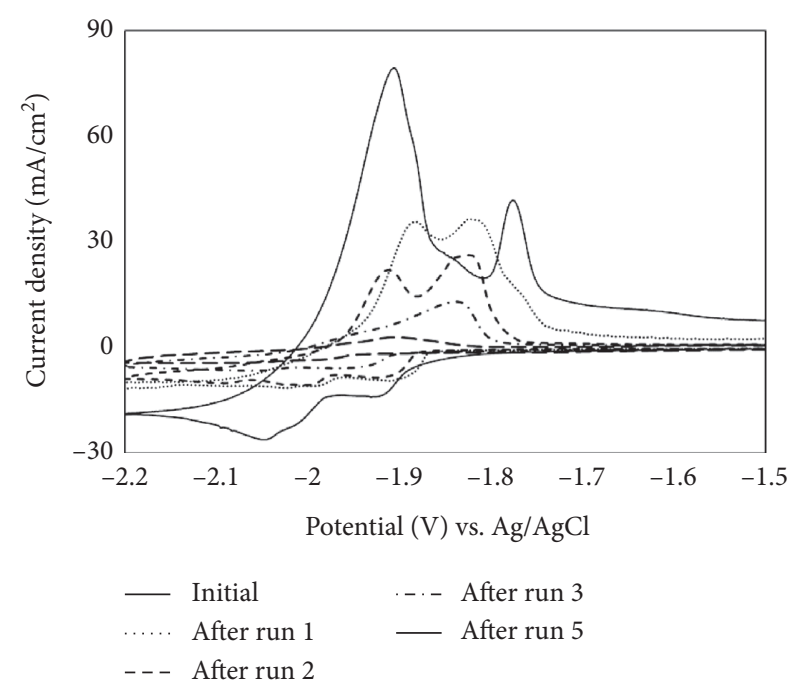

FIgURE 3: Cyclic voltammograms before and after each potentiostatic electrolysis run (scan rate $=100 \mathrm{mV} / \mathrm{s}$ ).

report, they presented the extraction of $\mathrm{Dy}$ from $\mathrm{LiCl}-\mathrm{KCl}$ melt containing $\mathrm{DyCl}_{3}$ and $\mathrm{GdCl}_{3}$ using $\mathrm{Mg}$ electrode. However, here, selective reduction of Dy was not examined.

In run 2 , the applied potential was $-1.90 \mathrm{~V}$, which is the same potential value with run 1 , using Mo wire electrode (surface area: $0.32 \mathrm{~cm}^{2}$ ). After $11 \mathrm{~h}$, the cyclic voltammetry was measured to check the removal of rare earth elements in the salt. As shown in Figure 3, the cathodic peaks decreased slightly, while the anodic peaks distinctly decreased. After the electrolysis for $11 \mathrm{~h}$, the salt composition of $\mathrm{Dy}^{3+}, \mathrm{Gd}^{3+}$, and $\mathrm{Mg}^{2+}$ was decreased as $0.08,0.22$, and $0.08 \mathrm{wt} \%$, respectively. In the runs $3 \sim 5$, the cathode was replaced from Mo wire to Mo coil to increase the electrode surface area $\left(3.37 \mathrm{~cm}^{2}\right)$ and to remove the elements in the salt as much as possible. The applied potentials of run $3 \sim 5$ were negatively increased from -1.90 to $-1.94 \mathrm{~V}$ because the EMP value before each run was shifted. For example, the EMP values before run $3 \sim 5$ were $-1.88,-1.91$, and $-1.93 \mathrm{~V}$ vs. $\mathrm{Ag} / \mathrm{AgCl}$. During the run 5, much higher current flowed so the

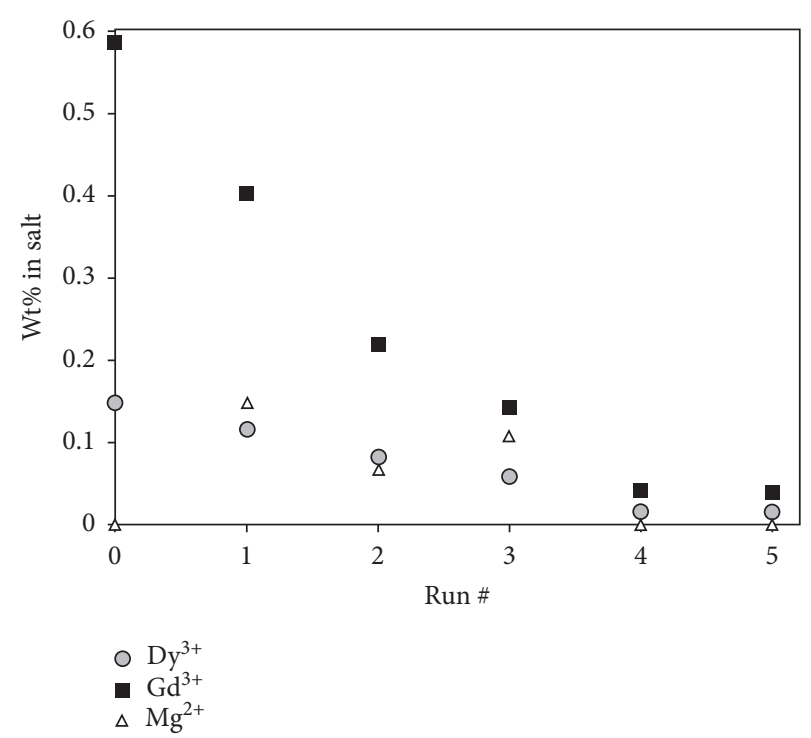

Figure 4: Composition of $\mathrm{Dy}^{3+}, \mathrm{Gd}^{3+}$, and $\mathrm{Mg}^{2+}$ in the salt before and after each electrolysis run.

electrolysis was stopped at $5 \mathrm{~h}$ of operation. After the electrodeposition runs, the redox peaks of the rare Earth elements in the salt were clearly diminished (Figure 3 ). Through the electrodeposition runs $3 \sim 5$, the concentration of $\mathrm{Dy}^{3+}$ and $\mathrm{Gd}^{3+}$ was decreased to 0.016 and $0.040 \mathrm{wt} \%$, respectively, and the $\mathrm{Mg}^{2+}$ was not detected. The removal efficiency of $\mathrm{Dy}^{3+}$ and $\mathrm{Gd}^{3+}$ was calculated to be about 83.5 95.2 and 91.6 95.2\%, respectively, even though the current efficiency was very low. To overcome the low current efficiency, the anodic reaction such as the chlorine gas evolution needs to be separated from the cathodic reaction such as the electrodeposition of metal ions in the salt. Also, an addition of $\mathrm{Cl}_{2}(\mathrm{~g})$ capturing unit may work to prevent the rechlorination of the metal deposits and to protect the $\mathrm{Mg}$ electrode.

The photographs of Mg electrode before and after the electrodeposition run 1 were presented in Figure 5. As shown in Figure 5(b), the RE deposit on Mg electrode was visually examined. The cross-sectional area of the RE deposit on Mg electrode was analyzed by SEM-EDS. Figure 6 is the cross-sectional SEM image of RE deposited Mg electrode, as shown in Figure 5(b). Two layers were observed in the crosssectional image by SEM (Figure 6(a)) and the layer consists of Dy, Gd, and Mg confirmed by EDS. It indicates the RE deposits were formed on the Mg surface (Figure 6(b)). The outer layer had slightly higher amount of RE, but it was not significant. It may be due to the interdiffusion of RE elements through Mg bulk phase. Also, there was no big difference in the concentration profiles of Dy and Gd in the cross-sectional area in Figure 6(b), which is expected from the salt analysis result. In case of Mo electrode, a distinguishable deposit on the electrode surface was not found, but black-mud like compound was observed on the bottom of the cell and it was difficult to collect as mentioned in the previous study [26]. Therefore, it needs to be consider to use of the alloy forming material and its ion for the attainment of $\mathrm{RE}$ recovery. 


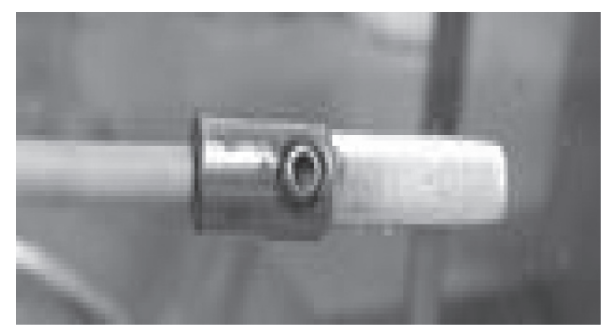

(a)

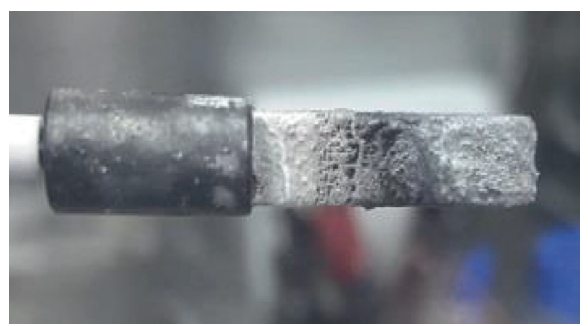

(b)

Figure 5: Photographs of Mg electrode (a) before and (b) after the electrodeposition run 1.

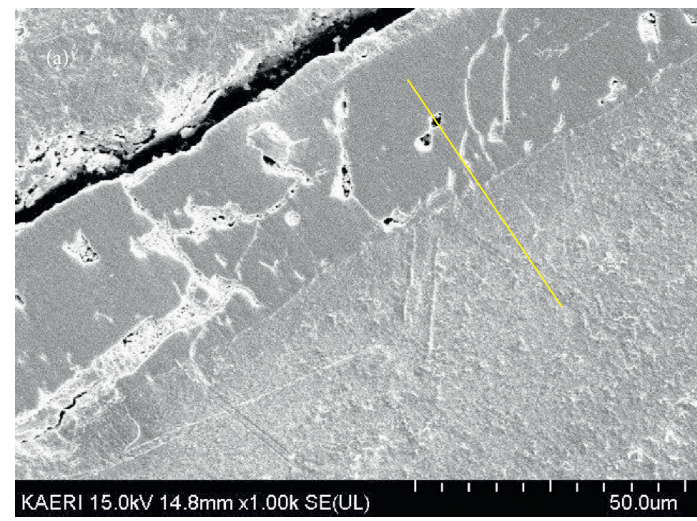

(a)

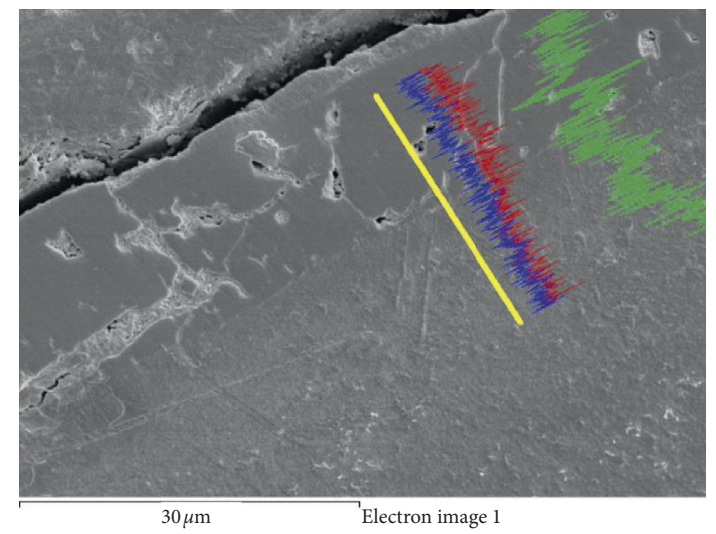

(b)

Figure 6: SEM (a) and EDS (b) analysis results for the cross-sectional area of RE deposited Mg electrode (green line: Mg, red line: Gd, blue line: Dy).

\section{Conclusions}

In this work, the electrochemical behavior of $\mathrm{DyCl}_{3}$ and $\mathrm{GdCl}_{3}$ in a $\mathrm{LiCl}-\mathrm{KCl}$ eutectic melt at $500^{\circ} \mathrm{C}$ was examined by performing $\mathrm{CV}$ and electrodeposition tests using Mo and $\mathrm{Mg}$ electrodes. The $\mathrm{CV}$ results exhibited a shift in the reduction potentials of $\mathrm{Dy}^{3+}$ and $\mathrm{Gd}^{3+}$ when using the $\mathrm{Mg}$ electrode, owing to the formation of $\mathrm{RE}-\mathrm{Mg}$ alloys. Furthermore, potentiostatic electrolysis tests were performed to remove Dy and Gd from the salt. The ICP-OES analysis of the salt samples indicated that $\mathrm{Dy}^{3+}$ and $\mathrm{Gd}^{3+}$ in the salt is removed using both of the $\mathrm{Mg}$ and Mo electrode with the removal efficiency of $\mathrm{Dy}^{3+}$ and $\mathrm{Gd}^{3+}$ was obtained as 83.5 95.2 and 91.6 95.2\%, respectively. The low current efficiency could be improved by adopting a $\mathrm{Cl}_{2}$ (g) venting system to prevent the rechlorination, protect the cathode material, and separate the electrodeposition reaction from the anodic reaction. The SEMEDS analysis of the deposited RE layer on the Mg electrode clarified that the reduced Dy and Gd existed in the form of RE-Mg alloy.

\section{Data Availability}

The data used to support the findings of this study are included within the article.

\section{Conflicts of Interest}

The authors declare that there are no conflicts of interest regarding the publication of this paper.

\section{Acknowledgments}

This work was supported by a National Research Foundation of Korea grant funded by the Korean Ministry of Science and ICT (MSIT) (grant no. 2017M2A8A5015079).

\section{References}

[1] J. J. Laidler, J. E. Battles, W. E. Miller, J. P. Ackerman, and E. L. Carls, "Development of pyroprocessing technology," Progress in Nuclear Energy, vol. 31, no. 1-2, pp. 131-140, 1997.

[2] C. E. Till and Y. I. Chang, Plentiful Energy: The Story of the Integral Fast Reactor, Create Space Independent, Scotts Valley, CA, USA, 2011.

[3] H.-S. Lee, G.-I. Park, K.-H. Kang et al., "Pyroprocessing technology development at KAERI," Nuclear Engineering and Technology, vol. 43, no. 4, pp. 317-328, 2011.

[4] T. Inoue and L. Koch, "Development of pyroprocessing and its future direction," Nuclear Engineering and Technology, vol. 40, no. 3, pp. 183-190, 2008.

[5] S. D. Herrmann and S. X. Li, "Separation and recovery of uranium metal from spent light water reactor fuel via 
electrolytic reduction and electrorefining," Nuclear Technology, vol. 171, no. 3, pp. 247-265, 2010.

[6] J.-H. Lee, Y.-H. Kang, S.-C. Hwang et al., "Electrodeposition characteristics of uranium in molten $\mathrm{LiCl}-\mathrm{KCl}$ eutectic and its salt distillation behavior," Journal of Nuclear Science and Technology, vol. 43, no. 3, pp. 263-269, 2006.

[7] J. H. Lee, Y. H. Kang, S. C. Hwang, E. H. Kim, J. H. Yoo, and H. S. Park, "Separation characteristics of a spent fuel surrogate in the molten salt electrorefining process," Journal of Materials Processing Technology, vol. 189, no. 1-3, pp. 268-272, 2007.

[8] F. Simpson, "Developments of Spent Nuclear Fuel Pyroprocessing Technology," Report No. INL/EXT-12-25124, Idaho National Laboratory, Idaho Falls, ID, USA, 2012.

[9] D. Vaden, S. X. Li, B. R. Westphal, K. B. Davies, T. A. Johnson, and D. M. Pace, "Engineering-scale liquid cadmium cathode experiments," Nuclear Technology, vol. 162, no. 2, pp. 124-128, 2008.

[10] S. X. Li, S. D. Herrmann, K. M. Goff, M. F. Simpson, and R. W. Benedict, "Actinide recovery experiments with benchscale liquid cadmium cathode in real fission product-laden molten salt," Nuclear Technology, vol. 165, no. 2, pp. 190-199, 2009.

[11] A.-r. Wu and C.-q. Xia, "Study of the microstructure and mechanical properties of Mg-rare earth alloys," Materials \& Design, vol. 28, no. 6, pp. 1963-1967, 2007.

[12] M. T. Harrison, H. E. Simms, A. Jackson, and R. G. Lewin, "Salt waste treatment from a $\mathrm{LiCl}-\mathrm{KCl}$ based pyrochemical spent fuel treatment process," Radiochimica Acta, vol. 96, pp. 295-301, 2008.

[13] Y.-Z. Cho, T.-K. Lee, J.-H. Choi, H.-C. Eun, H.-S. Park, and G.-I. Park, "Eutectic (LiCl-KCl) waste salt treatment by sequencial separation process," Nuclear Engineering and Technology, vol. 45, no. 5, pp. 675-682, 2013.

[14] H. C. Eun, J. H. Kim, Y. Z. Cho et al., "An optimal method for phosphorylation of rare earth chlorides in $\mathrm{LiCl}-\mathrm{KCl}$ eutectic based waste salt," Journal of Nuclear Materials, vol. 442, no. 13, pp. 175-178, 2013.

[15] Y.-Z. Cho, T.-K. Lee, H.-C. Eun, J.-H. Choi, I.-T. Kim, and G.-I. Park, "Purification of used eutectic (LiCl-KCl) salt electrolyte from pyroprocessing," Journal of Nuclear Materials, vol. 437, no. 1-3, pp. 47-54, 2013.

[16] Y. Castrillejo, M. R. Bermejo, E. Barrado, and A. M. Martínez, "Electrochemical behaviour of erbium in the eutectic LiCl$\mathrm{KCl}$ at $\mathrm{W}$ and $\mathrm{Al}$ electrodes," Electrochimica Acta, vol. 51, no. 10, pp. 1941-1951, 2006.

[17] M. R. Bermejo, F. de la Rosa, E. Barrado, and Y. Castrillejo, "Cathodic behaviour of europium (III) on glassy carbon, electrochemical formation of $\mathrm{Al} 4 \mathrm{Eu}$, and oxoacidity reactions in the eutectic LiCl-KCl," Journal of Electroanalytical Chemistry, vol. 603, no. 1, pp. 81-95, 2007.

[18] M. R. Bermej, E. Barrado, A. M. Martíneb, and Y. Castrillejo, "'Electrodeposition of Lu on W and Al electrodes: electrochemical formation of $\mathrm{Lu}-\mathrm{Al}$ alloys and oxoacidity reactions of $\mathrm{Lu}(\mathrm{III})$ in the eutectic LiCl-KCl," Journal of Electroanalytical Chemistry, vol. 617, pp. 85-100, 2008.

[19] Y. Castrillejo, P. Fernández, J. Medina, P. Hernández, and E. Barrado, "Electrochemical extraction of samarium from molten chlorides in pyrochemical processes," Electrochimica Acta, vol. 56, no. 24, pp. 8638-8644, 2011.

[20] A. Sailla, M. Gibilaro, L. Massot, P. Chamelot, P. Taxil, and A. M. Affoune, "Electrochemical behaviour of dysprosiu$\mathrm{m}$ (III) in LiF-CaF2 on Mo, Ni and Cu electrodes," Journal of Electroanalytical Chemistry, vol. 642, no. 2, pp. 150-156, 2010.
[21] H. Tang, Y.-D. Yan, M.-L. Zhang et al., "Fabrication of Mg-Pr and Mg-Li-Pr alloys by electrochemical co-reduction from their molten chlorides," Electrochimica Acta, vol. 107, pp. 209-215, 2013.

[22] Y.-S. Yang, M.-L. Zhang, W. Han et al., "Selective electrodeposition of dysprosium in $\mathrm{LiCl}-\mathrm{KCl}-\mathrm{GdCl} 3-\mathrm{DyCl} 3$ melts at magnesium electrodes: application to separation of nuclear wastes," Electrochimica Acta, vol. 118, pp. 150-156, 2014.

[23] M. Zhang, Y. Yang, W. Han, M. Li, Y. Sun, and Y. Yan, "Separation of $\mathrm{SmCl} 3$ from $\mathrm{SmCl} 3-\mathrm{DyCl} 3$ system by electrolysis in $\mathrm{KCl}-\mathrm{LiCl}-\mathrm{MgCl} 2$ molten salts," Energy Procedia, vol. 39, pp. 375-381, 2013.

[24] W. Shidong, L. Quan, Y. Xiushen, S. Qingguo, and W. Zhijian, "Electrolytic Preparation of Mg-La alloy in chloride molten salt: effect of electrolyte composition," Rare Metal Materials and Engineering, vol. 44, no. 7, pp. 1623-1628, 2015.

[25] T. B. Massalski, Binary Alloy Phase Diagrams, ASM International, Cleveland, OH, USA, 1986.

[26] T. Jiang, N. Wang, S.-M. Peng, M. Li, W. Han, and M.-L. Zhang, "Electrochemical formation of Mg-Lu alloy and alloy layer in molten LiCl-KCl," Journal of Alloys and Compounds, vol. 658, pp. 198-209, 2016. 